\title{
Curitiba Walk City: Revitalization of city center by making the city walking friendly, and sustainable
}

\author{
Henrique Pissaia de Souza ${ }^{1}$, Pedro Paulo Mulaski
}

\begin{abstract}
This paper provides an innovative approach to deal with urban problems in the city of Curitiba, Brazil. The paper mixes urban, architecture and economic planning in an applied environmental friendly urban intervention. It proposes a walking system in the city using the already pedestrian walkways implemented in the city with new ones and the construction of pedestrian sky walkways as several implemented around the world, especially in Asia, totaling $7 \mathrm{~km}$ of walkways in the city center. The project is already in urban scale, showing the feasibility of the project. It is shown that with the project traffic problems will be minimized, safety will be improved; the commercial area will be revitalized and several environmental will be preserved in an economically feasible project.
\end{abstract}

Keywords: walk city, Curitiba, walkways, sky walkways, sustainable development

\section{Introduction}

This paper aims to introduce a project of an integrated system of elevated walkways (sky walkways), pedestrian walkways, squares, parks, bus stations, offices and malls. The system is inspired in models of success such as the ones implemented in Hong Kong, Kuala Lumpur, Bangkok, among others; however integrating with the city unique set of pedestrian walkways, squares and parks. The system will comprehend $7 \mathrm{~km}$, 4,3 miles, of walkable routs in the heart of the city, bringing more comfort, safety, faster commuting, traffic improvements, environmental improvement and commercial revitalization. The project aims to provide an innovative approach, however on the other hand feasible, with few externalities and relative low costs to the public administration.

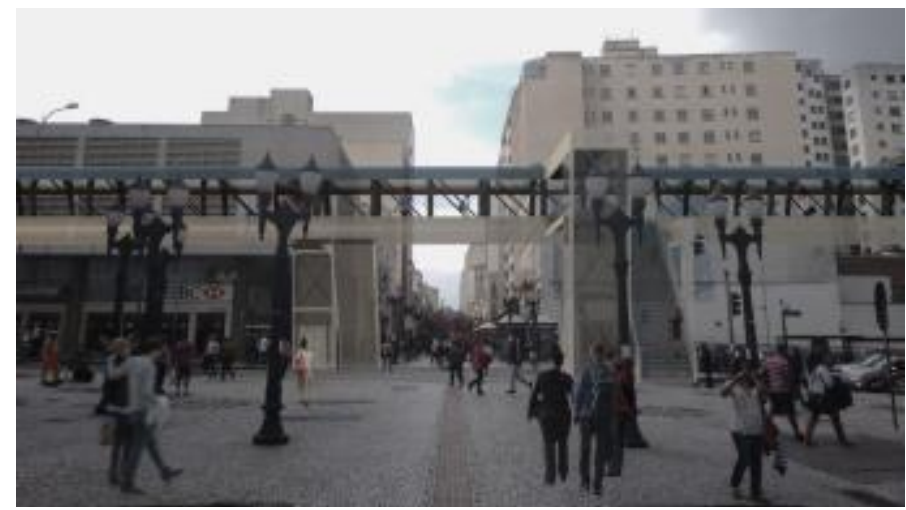

Board 1: Main existing pedestrian walkway of the city cut by the proposed sky walkway. Modeling over real picture.

$\mid{ }^{1}$ General Coordinator of Strategic Alliances Unit at FONPLATA. PhD candidate in International Economics, University of International Business and Economics - UIBE; Beijing, China

${ }^{2}$ Architect and Urbanist, Pontifícia Universidade Católica do Paraná - PUC-PR. 


\section{The Proposed System}

\subsection{Curitiba}

Curitiba is the Capital State of Parana, a State in the south of Brazil. The city has almost 2 million inhabitants and with a metropolitan area comprised by 26 municipalities with a total population of more than 3 million [1]. The city is called the model capital and the green capital; due to its huge amount of parks, squares, public gardens, the clean streets and a good transportation system [2].

Curitiba used to be recognized by its vanguard in public transportation and urban locomotion, with the internationally exported BRT (Bus Rapid Transit) corridor, now present in 180 cities around the world, (even having a World Bank report Eco ${ }^{2}$ Cities) [3]. However, the city is losing its quality, mainly due to an avalanche of cars, totaling $1,516,468$, according to late official census [4] - making it the Brazilian city with the higher proportion of cars for inhabitant, with 1 car for every 1.8 inhabitant - and the lack of new transport developments. Projects to implement a subway or a surface rapid train have been discussed and re-discussed for more than 10 years, with its official studies started in 2002, and a cost of R $\$ 23.3$ million, US\$ 7.3 million[5].

During last Mayor's election process, in 2016, solutions for the traffic jams and public transportation, in the city center, was one of the main points of discussions among the candidates [6]. Nevertheless, no concrete proposal or project was presented. Our project is here to try to fill in this gap.

\subsection{Project Specifications}

The new walking skyways will comprehend $4 \mathrm{~km}, 2,5$ miles, connecting the State Houses, Justice Courts, shopping malls, offices, hospitals, the bus station, bus terminals, bus stops, universities, theaters, social security office and other public offices, parks, squares and pedestrian walkways (these with total extension of $3 \mathrm{~km}, 1,9$ miles), totaling $7 \mathrm{~km}, 4,3$ miles, of walkable system.

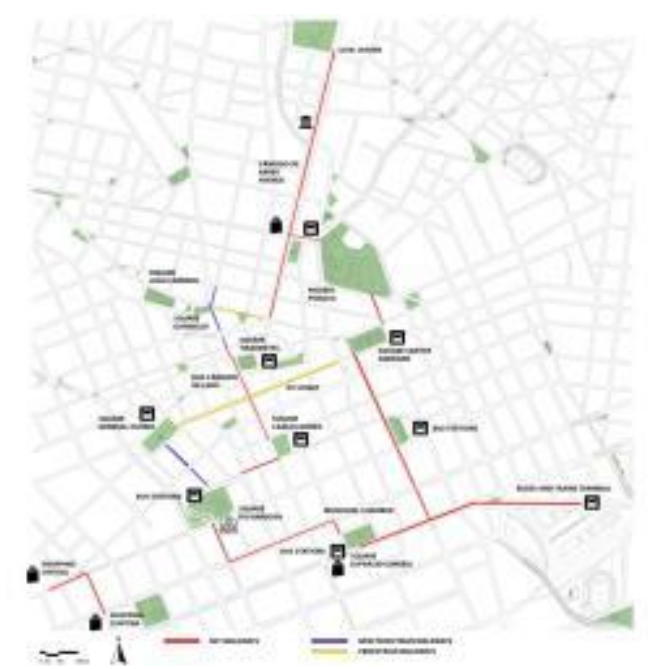

Board 2: Whole system proposed integrating existing pedestrian walkways, and new walkways and sky walkways, in real scale. 
The walking skyways will stand 5 meter higher than the street level, it will have the internal width of 3 meters and 2,5 meters of height. They will have stairs, escalators in the main areas and elevators to provide access to people with disabilities, and direct entrances to shopping malls and buildings. Also, they will have video surveillance systems.

The sky walkways will bring an aesthetic component. The design will make reference to the glass' tube stations, a city trademark and will become a new city symbol.

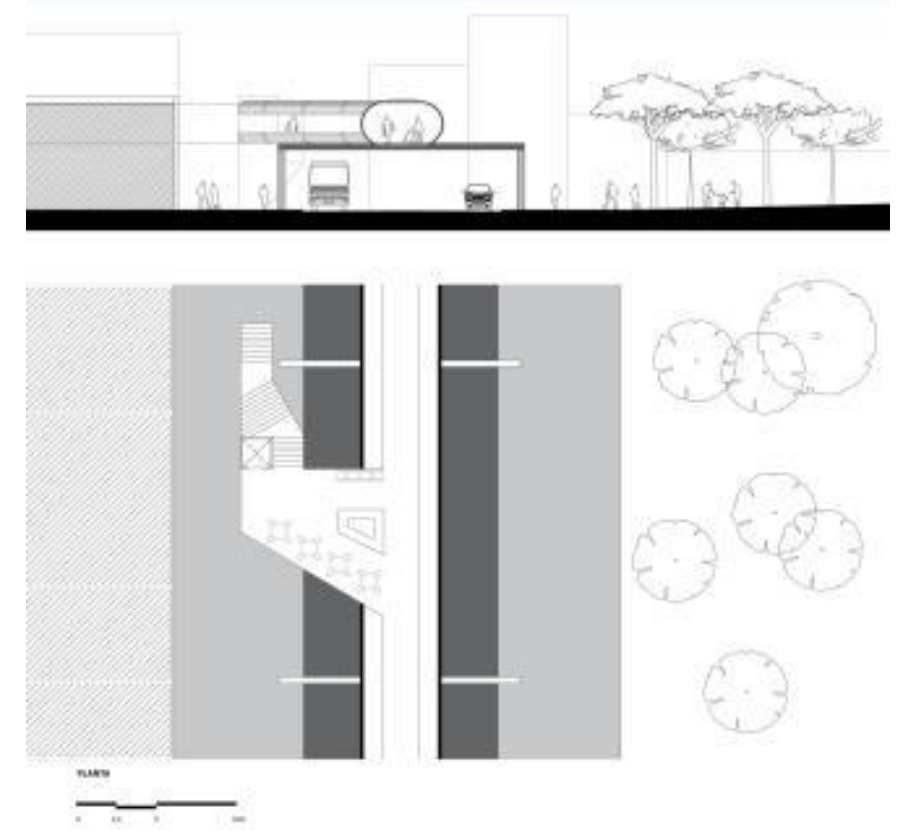

Board 3: Prototype of the structure and access points of sky walkway, in real scale.

\subsection{Environmental Aspects}

The project will be environment friendly. We propose the implementation of vertical gardens, solar energy panels and rain water retention system.

To keep the city green label, we propose the implementation of vertical gardens in its structural pillars. They will help to minimize the impact of the metal and concrete structures to be installed. The green pillars are already in use in several countries.

The sky walkways will have solar panels in their rooftops in specific points. The solar panels will provide energy to the sky walkways and to traffic lights and public lights system. It will have a parallel grid to these lights, which will allow the traffic lights and central area's lights to be working even in blackout periods - still relative common in the city, especially in rainy days.

To complete the environment friendly structure will have a rain water retention system. The roof top of the sky walkway will have a system to canalize and then storage the water of the rain. This water can be used to wash the streets and to irrigate the city gardens. 

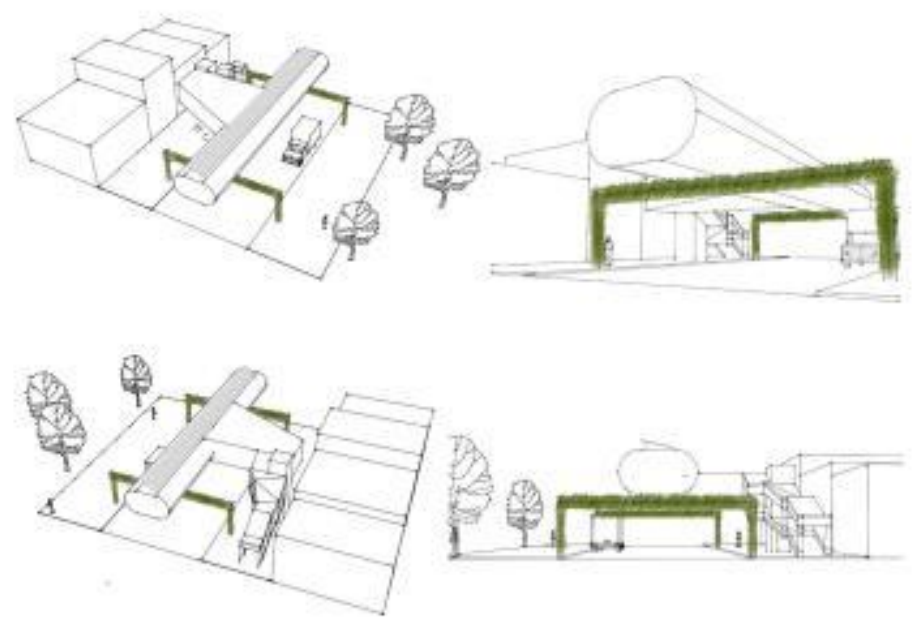

Salar Panels

Vertical Gardens

Board 4: Prototype with the structure from different angles and the environmental structures.

\subsection{Costs and Feasibility}

The concept is not a utopic or unfeasible project. It's a model already tested and successfully adopted specially in Asia. The construction and maintenance should be made in a Public-Private Partnership - PPP. The hotels and commercial centers that will have direct connections with the system must pay for part of the costs and be responsible for the maintenance of part of the sky walkway.

The management should be done on a private concessions, the manager should be responsible for the general management and maintenance of the sky walkways. The revenues will come from spaces destined to commercial advertisements and commercial sales points (food, beverage, art, books...) and for Wi-Fi provided by mobile phone companies.

\section{Overal Benefits}

\subsection{Pedestrian Benefits}

The system will bring more comfort and security to pedestrians. In Curitiba it rains at every two days, on average, and is the coldest capital of Brazil. The closed sky walkways will provide a controlled environment preventing people from rain and cold weather. People will not cross some streets anymore, which eliminates the risk of car hitting people. Moreover, the video security system will minimize robberies, a problem in the region.

Conjugated with the existing and future pedestrian walkways, squares and parks, the system will be a $7 \mathrm{~km}, 4.3$ miles, of walkable system in the city center, integrating with bus terminal, bus stations, services and shopping areas. It will increase the comfort and safety of the population. Also, it will make locomotion much faster, allowing people to 
not stop in several street lights to cross streets, saving around 30 seconds to 2 minutes, in each street crossing.

\subsection{Traffic Benefits}

Due to the safety and comfort added by the system, we believe more people will use public transportation to go to the city center. It will put less pressure on the traffic system, diminishing traffic jams.

The system proposed will also match with the car calm ways already existent - zones where the cars can be driven at $25 \mathrm{miles} / \mathrm{h}, 40 \mathrm{~km} / \mathrm{h}$ maximum. This combination will allow the removal of several traffic lights. In a preliminary study (board 5). With the implementation of only one section of sky walkway, with the extension of $500 \mathrm{KM}, 300$ Miles, 9 traffic lights could be removed. Moreover, it will save around 30 seconds in every traffic lights cycle, caused by the unnecessary pedestrian lights aperture.

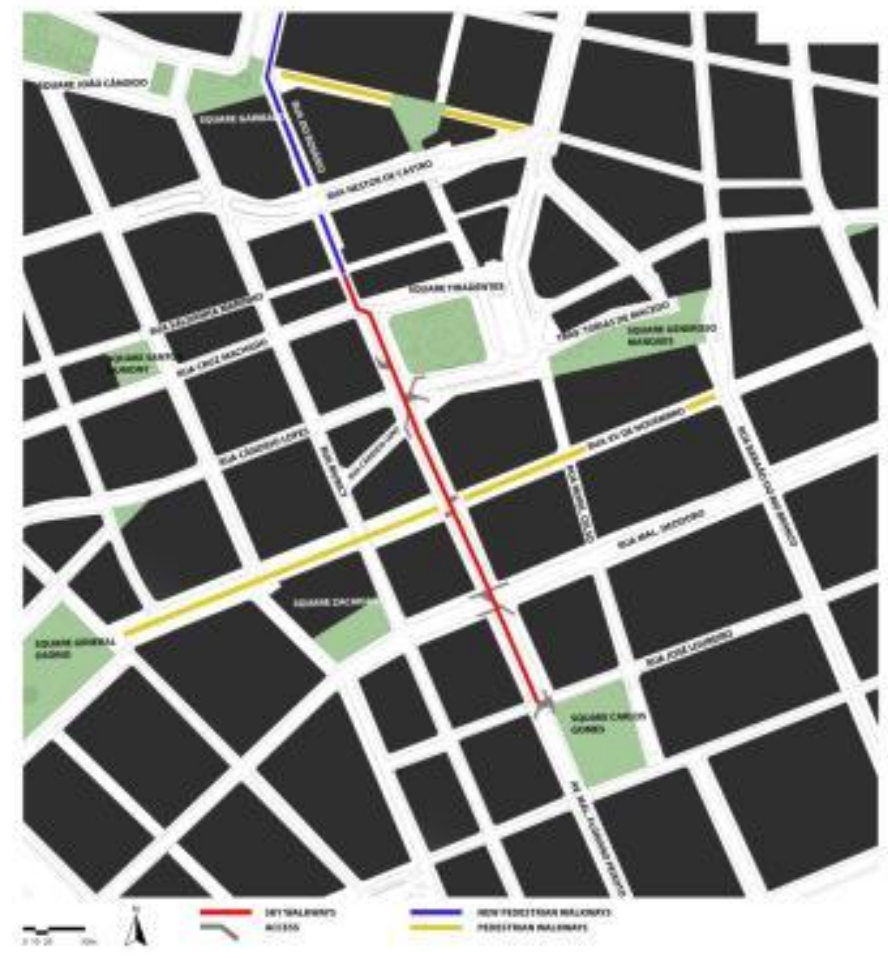

Board 5: Preliminar study of the first section proposed, in real scale.

\subsection{Commercial Revitalization}

Most of the streets comprehended in the system have decadent or inexistent commerce. The sky walkway will allow the creation of new commercial center, office buildings, garages and shopping malls, bringing life back to these streets.

The system can be a model to other parts of the city and other cities in Brazil, and make the integration with future subways, BRTs and surface trains that will be implemented in the future. 


\section{Conclusion}

We proposed a system that is inexistent in Latin America, conjugating $7 \mathrm{~km}$ of pedestrian walkways and sky walkways, the main goal of the project is adapt successful experiences to a new reality and bring some innovative ideas to the city problems. The project can be used in part or in totality by the urban planners, also be an idea to other cities in the country and in the region.

Of course the costs must be refined and other technical specifications must be done, however we understand it's a good beginning to discuss new ways to address old problems.

\section{References}

Curitiba's municipality website. Available in: http://www.curitiba.pr.gov.br/idioma/ingles, access made in $25 / 06 / 2017$.

Adler, David. Cities. The story of cities. Story of cities \#37: how radical ideas turned Curitiba into Brazil's 'green capital' The Guardian, 6 may $2017 . \quad$ Available in: https://www.theguardian.com/cities/2016/may/06/story-of-cities-37-mayor-jaime-lernercuritiba-brazil-green-capital-global-icon, access made in 25/06/2017.

Suzuki, Hiroaki. Dastur, Arish. Nanae, Sebastian Moffatt. Maruyama, Yabuki Hinako. Eco2 Cities Ecological Cities as Economic Cities. The world Bank 2010. Available in: http://siteresources.worldbank.org /INTURBANDEVELOPMENT/Resources/336387-1270074782769/Eco2_Cities_Book.pdf, access made in 26/06/2017

Brazilian Institute of Statistics. Available in: https://cidades.ibge.gov.br/v4/brasil/pr/curitiba /pesquisa/22/28120?detalhes=true, access made in 25/06/2017.

Frey, Joao Guilherme. Martins, Rafael Moro . Ainda no papel Metro de Curitiba ja custou R $\$ 23,3$ milhoes em dinheiro publico. Gazeta do Povo, 18/11/29016. . Available in: http://www.gazetadopovo.com.br/vida-e-cidadania/ainda-no-papel-metro-curitibano-ja-custou-r233-milhoes-em-dinheiro-publico-dzi1e82af9hr0b0flu4afy1na, access made in 26/06/2017.

G1 Parana. Eleicoes 2016, 29 oct 2016. Available in: http://g1.globo.com/pr/parana/eleicoes/2016/noticia /2016/10/candidatos-prefeito-apresentam-propostas-para-curitiba-em-debate.html, access made in $26 / 06 / 2017$. 